\title{
Functional Interaction of Melatonin Receptors and D1 Dopamine Receptors in Cultured Chick Retinal Neurons
}

\author{
P. Michael luvone and Jiwei Gan \\ Department of Pharmacology, Emory University School of Medicine, Atlanta, Georgia 30322-3090
}

The possible interaction of melatonin receptors and D1 dopamine receptors was investigated in neural cells prepared from embryonic day 8 chick retinas and cultured for $6 \mathrm{~d}$. Dopamine stimulated CAMP accumulation in cultured retinal cells. This effect of dopamine was antagonized by addition of dopamine receptor antagonists (haloperidol and SCH23390) or melatonin receptor agonists (melatonin, 2-iodomelatonin, and 6-chloromelatonin). The inhibition of dopamine-stimulated CAMP accumulation by melatonin was concentration dependent, with half-maximal inhibition at approximately $160 \mathrm{pm}$. Melatonin inhibited the effect of dopamine at all dopamine concentrations, suppressing the maximal response to the neurotransmitter by approximately $70 \%$. Melatonin also inhibited the stimulation of cAMP accumulation by SKF 82958, a selective D1 dopamine receptor agonist. Pretreatment of cultures with pertussis toxin had no significant effect on dopamine-stimulated cAMP accumulation, but inhibited the response to melatonin. In contrast to its effect on cAMP accumulation, melatonin had no effect on dopamine-stimulated inositol phosphate accumulation. These results suggest that melatonin receptors are coupled to dopamine receptor-regulated adenylate cyclase via an inhibitory $\mathbf{G}$ protein, and demonstrate another mechanism, in addition to inhibition of dopamine release, through which melatonin can modulate dopaminergic neurotransmission.

[Key words: melatonin receptors, D1 dopamine receptors, cAMP, inositol phosphates, pertussis toxin, retina, receptor cross talk]

Melatonin and dopamine are putative neuromodulators with opposing roles in retinal physiology (Besharse et al., 1988). Melatonin is synthesized in and released from photoreceptor cells (e.g., Redburn and Mitchell, 1989; Iuvone et al., 1990; Cahill and Besharse, 1992; Zawilska and Iuvone, 1992; Thomas et al., 1993; Wiechmann and Craft, 1993), and dopamine is synthesized in amacrine and interplexiform cells (reviewed in Ehinger, 1977; Iuvone, 1986). In retina, melatonin activates rod photoreceptor disk shedding (Besharse and Dunis, 1983; Besharse et al., 1984), and promotes dark-adaptive retinomotor movements (Cheze and Ali, 1976; Pang and Yew, 1979; Pierce and Besharse, 1985). In contrast, dopamine inhibits rod photoreceptor

\footnotetext{
Received July 5, 1994; revised Sept. 14, 1994; accepted Sept. 19, 1994.

We gratefully acknowledge Bonnie Johnson for assistance in the preparation of Figure 5, Marian Osborne for preparing tables, and Deborah Kline for proofreading. This research was supported in part by NIH Grant EY-04864.

Correspondence should be addressed to P. Michael Iuvone at the above address.

Copyright (C) 1995 Society for Neuroscience $0270-6474 / 95 / 152179-07 \$ 05.00 / 0$
}

disk shedding (Pierce and Besharse, 1986; Besharse et al., 1988) and promotes light-adaptive retinomotor movements (Picree and Besharse, 1985; Dearry and Burnside, 1986). Melatonin inhibits electrically stimulated and light-evoked release of ACh (Mitchell and Redburn, 1991), while dopamine stimulates ACh release (Hensler and Dubocovich, 1986). Melatonin enhances the sensitivity of horizontal cells (Wiechmann et al., 1988), and decreases the trans-epithelial potential of retinal pigment epithelial (RPE) cells and the c-wave of the electroretinogram (ERG) (Nao-I et al., 1989; Rudolf et al., 1992). Dopamine decreases the response of horizontal cells to full-field stimulation (Mangel and Dowling, 1987), and increases the transepithelial potential of RPE cells and the c-wave amplitude (Gallemore and Steinberg, 1990; Rudolf et al., 1992). Melatonin is synthesized and released in retina in darkness, and in some species, under the influence of a circadian clock (Hamm and Menaker, 1980; Besharse and Iuvone, 1983; Redburn and Mitchell, 1989), while dopamine synthesis and release in retina is stimulated by steady or flickering light (Kramer, 1971; Iuvone et al., 1978; Dowling and Watling, 1981; Parkinson and Kando, 1983; Godley and Wurtman, 1988; Boatright et al., 1989). Melatonin inhibits dopamine synthesis and release (Dubocovich, 1983; Nowak, 1988; Nowak et al., 1992; Boatright et al., 1994), and melatonin synthesis and release are inhibited by dopamine (Iuvone and Besharse, 1986; Iuvone et al., 1987, 1990; Zawilska and Iuvone, 1989; Cahill and Besharse, 1991). Thus, melatonin and dopamine appear to form the basis of a neurochemical feedback loop that regulates opposing physiological processes.

High-affinity melatonin receptors have been characterized in retina using $2{ }^{-125} \mathrm{I}$-iodomelatonin as a radioligand (e.g., Dubocovich and Takahashi, 1987; Laitinen and Saavedra, 1990; Wiechmann and Wirsig-Wiechmann, 1991). Occupation of melatonin receptors in retinal membranes inhibits forskolin-stimulated adenylate cyclase (Niles et al., 1991). We recently reported that cultured neural cells prepared from chick embryo retina have 2-iodomelatonin binding sites, and that occupation of melatonin receptors in these cultures inhibits forskolin-stimulated cAMP accumulation (Iuvone and Gan, 1994a). Intact retina and retinal cell cultures are rich in D1 dopamine receptors, activation of which stimulates adenylate cyclase (Brown and Makman, 1972; Watling et al., 1979; DeMello et al., 1982). In this study, we examined the possible interaction of melatonin receptors and D1 dopamine receptors in cultured retinal cells, and report that these receptors appear to be colocalized on retinal neurons and have opposing effects on cAMP formation.

A preliminary report of some of these results has been published in abstract form (Iuvone and Gan, 1992). 


\section{Materials and Methods}

Cell cultures. Neuronal cell cultures were prepared from embryonic chick retina as described by Adler et al. (1984), with minor modifications (Avendano et al., 1990). Briefly, eggs of White Leghorn chickens (Gallus domesticus) were incubated at $37.5 \pm 0.5^{\circ} \mathrm{C}$ in a humidified incubator. Cultures were prepared from embryonic day 8 neural retina. Neural retinas, apparently free of pigment epithelial or other cells, were dissected and dissociated by trypsinization $(0.25 \%$ trypsin for $20 \mathrm{~min}$ at $37^{\circ} \mathrm{C}$ ) and trituration. Cells were seeded into Falcon culture dishes at a density of $4.5 \times 10^{6}$ cells $/ 60 \mathrm{~mm}$ dish. The culture dishes were pretreated with $0.1 \mathrm{mg} / \mathrm{ml}$ of polyornithine in $0.15 \mathrm{M}$ sodium borate $(\mathrm{pH}$ 8.4), washed sequentially with $\mathrm{H}_{2} \mathrm{O}$ and medium 199 , and incubated with culture medium containing $20 \%$ defined fetal bovine serum $(\mathrm{Hy}$ clone, Logan, UT) before seeding. Cells were cultured for $6 \mathrm{~d}$ in $6 \mathrm{ml}$ of medium 199 supplemented with $10 \%$ fetal bovine serum, linoleic acid-bovine serum albumin $(110 \mu \mathrm{g} / \mathrm{ml}), 2 \mathrm{~mm}$ glutamine, and penicillin $\mathrm{G}(100 \mathrm{U} / \mathrm{ml})$, at $37^{\circ} \mathrm{C}$ under an atmosphere of $5-6.5 \% \mathrm{CO}_{2}$ in air. All measurements were made after $6 \mathrm{~d}$ of culture. The following three cell types were found in the cultures: multipolar neurons, photoreceptors, and apparently undifferentiated round cells.

Assay of cAMP formation. The synthesis of 'II-cAMP in cells prelabeled with ${ }^{3} \mathrm{H}$-adenine was determined by a modification of the method of Shimizu et al. (1969). Culture medium was removed by aspiration and replaced by $3 \mathrm{ml}$ of balanced salt solution (BSS; in $\mathrm{mM}: \mathrm{NaCl}$, 125.4; KCl, 3.6; $\mathrm{MgCl}_{2}, 1.2 ; \mathrm{CaCl}_{2}, 1.15 ; \mathrm{NaHCO}_{3}, 22.6 ; \mathrm{Na}_{2} \mathrm{HPO}_{4}$, $0.4 ; \mathrm{NaH}_{2} \mathrm{PO}_{4}, 0.1 ; \mathrm{Na}_{2} \mathrm{SO}_{4}, 1.2 ;$ D-glucose, 10) containing $5 \mu \mathrm{Ci}$ of $2,8-{ }^{3} \mathrm{H}$-adenine $(20.7 \mathrm{Ci} / \mathrm{mmol})$. Cells were returned to the incubator for $2 \mathrm{hr}$, after which the adenine solution was replaced by $2.85 \mathrm{ml}$ of BSS, containing test compounds as indicated. After a 10 min preincubation, $150 \mu 1$ of aqueous ascorbate $(0.1$ or $1 \mathrm{mM})$, with or without dopamine or SKF 82958 was added. All samples were incubated for $20 \mathrm{~min}$. Melatonin and related drugs were present at the indicated concentrations during the $10 \mathrm{~min}$ preincubation and $20 \mathrm{~min}$ incubation periods. The incubation was terminated by addition of $250 \mu \mathrm{l}$ of $77 \%$ trichloroacetic acid. Culture dishes were scraped with a spatula, and cells and medium were transferred to tubes. The dishes were washed with $0.5 \mathrm{ml}$ of BSS, and the wash was added to the tubes. An aliquot $(50 \mu \mathrm{l})$ of $10 \mathrm{~mm}$ cAMP was added as carrier. Samples were homogenized with a Tekmar Tissumizer, and centrifuged at $30,000 \times g$ for $15 \mathrm{~min}$. Aliquots $(50 \mu \mathrm{l})$ of supernatant fraction were taken for determination of total radioactivity. ${ }^{3} \mathrm{H}-\mathrm{cAMP}$ was isolated by sequential chromatography on Dowex $50 \mathrm{~W}-\mathrm{X} 4$ and alumina as described by Minneman et al. (1979), except that the bed dimension of the Dowex $50 \mathrm{~W}-\mathrm{X} 4$ columns was $0.8 \times 3$ $\mathrm{cm}$. Columns were calibrated for recovery using external standards of ${ }^{3} \mathrm{H}$-cAMP, and standards were run with each assay. The data were corrected for recovery and are expressed as percent conversion ( ${ }^{3} \mathrm{H}-\mathrm{c}$ AMP $\times 100 /$ total ${ }^{3} \mathrm{H}$ ) or as percentage of dopamine-stimulated cAMP accumulation. Dopamine-stimulated cyclic AMP accumulation is defined as the increment of cAMP above basal levels elicited by dopamine (accumulation in the presence of dopamine minus basal accumulation in the absence of added neurotransmitter).

In some experiments, cells were pretreated with $30 \mathrm{ng} / \mathrm{ml}$ of pertussis toxin, which was added directly to the culture medium on the fifth day in vitro. After $18 \mathrm{hr}$ the culture medium containing pertussis toxin was removed and replaced with BSS without toxin. Samples were then processed as described above.

The experiments described in this article were conducted over a three year period with cells grown in the presence of four different lots of fetal bovine serum (Hyclone defined serum lots 991, 2034, 2053, 2280). Absolute values of cAMP accumulation varied with the different serum lots, but the responses to dopamine and melatonin were similar with all lots. In the earlier experiments of this study (see Figs. 1, 3; Tables 4, 5 ), incubations were conducted in the presence of $5 \mu \mathrm{M}$ ascorbate, with or without dopamine. Under these conditions, $200 \mu \mathrm{M}$ dopamine was required to elicit a large cAMP response. Subsequently, we observed that dopanine was more potent in the presence of $50 \mu \mathrm{M}$ ascorbate, eliciting a maximal response at approximately $10 \mu \mathrm{M}$ (see Fig. 2). All subsequent experiments were conducted with the higher concentration of antioxidant. cAMP responses to high or low concentrations of dopamine were antagonized by dopamine receptor blockers (see Fig. 1, Table 1), and melatonin produced the same response under both of these conditions.

Assay of inositol phosphate accumulation. Cells were prelabeled with ${ }^{3} \mathrm{H}$-myo-inositol $(0.67 \mu \mathrm{Ci} / \mathrm{ml})$ for $4-5 \mathrm{~d}$. Inositol phosphate accumulation was determined by a modification of previously described meth-
Table 1. Dopamine-stimulated cAMP accumulation in cultured retinal neurons: antagonism by $\mathrm{SCH} 23390$

\begin{tabular}{lll} 
Addition & $N$ & $\begin{array}{l}\text { cAMP accumulation } \\
\text { (\% conversion) }\end{array}$ \\
\hline Vehicle & 5 & $0.19 \pm 0.01$ \\
SCH23390 $(20 \mu \mathrm{M})$ & 6 & $0.15 \pm 0.01$ \\
Dopamine $(10 \mu \mathrm{M})$ & 6 & $1.00 \pm 0.03^{\circ}$ \\
Dopamine $+\mathrm{SCH} 23390$ & 6 & $0.15 \pm 0.01$
\end{tabular}

cAMP accumulation was determined as described in Materials and Methods. SCH23390 was added 10 min prior to addition of dopamine.

${ }^{a} p<0.01$ versus all other groups.

ods (Berridge et al., 1982; Wilson et al., 1990). On the sixth day in vitro, culture medium was removed and washed with $3 \mathrm{ml}$ of lithiumBSS (LiBSS): $10 \mathrm{~mm} \mathrm{LiCl}, 115.4 \mathrm{mM} \mathrm{NaCl}, 3.6 \mathrm{~mm} \mathrm{KCl}, 1.2 \mathrm{~mm}$ $\mathrm{MgCl}_{2}, 1.15 \mathrm{mM} \mathrm{CaCl}_{2}, 22.6 \mathrm{~mm} \mathrm{NaHCO}, 0.4 \mathrm{mM} \mathrm{Na}_{2} \mathrm{HPO}_{4}, 0.1 \mathrm{~mm}$ $\mathrm{NaH}_{2} \mathrm{PO}_{4}, 1.2 \mathrm{~mm} \mathrm{Na}_{2} \mathrm{SO}_{4}, 0.029 \mathrm{~mm}$ EDTA; $10 \mathrm{~mm}$ D-glucose. LiBSS $(2.85 \mathrm{ml})$ was added to each dish, and cells were preincubated for 10 min. Test compounds or vehicle were subsequently added in a volume of $0.15 \mathrm{ml}$ and samples were incubated for $60 \mathrm{~min}$. The incubation medium was then aspirated, and $0.75 \mathrm{ml}$ of ice-cold methanol added. Cells were scraped from the dishes with a spatula and added to a tube containing $0.66 \mathrm{ml}$ of chloroform. Dishes were washed with $0.66 \mathrm{ml}$ of distilled water, which was added to the cell suspension. Samples were sonicated for $10 \mathrm{sec}$ and centrifuged at $10,000 \times g$ for $5 \mathrm{~min}$ to separate aqueous and organic phases. ${ }^{3} \mathrm{H}$-Inositol phosphates were isolated from the aqueous phase by anion exchange chromatography and measured by liquid scintillation counting as described by Wilson et al. (1990). Aliquots of the organic phase were counted to determine ${ }^{3} \mathrm{H}$-inositol incorporation into lipid. Percent hydrolysis was calculated by the dividing the amount of ${ }^{3} \mathrm{H}$-inositol phosphates formed by the total ${ }^{3} \mathrm{H}$-inositol incorporated.

Data analysis. Data are expressed as mean \pm standard error of the mean. Comparisons of group means between two groups were made with the Student's $t$ test, and among multiple groups with analysis of variance and Student-Newman-Keuls post hoc test. $\mathrm{EC}_{50}$ values were determined using the ALLFIT program (DeLean et al., 1978).

Materials. ${ }^{3} \mathrm{H}$-cAMP and ${ }^{3} \mathrm{H}$-adenine were obtained from Du Pont/ New England Nuclear (Boston, MA). ${ }^{3} \mathrm{H}$-myo-inositol $(20 \mathrm{Ci} / \mathrm{mmol})$ was from American Radiolabeled Chemicals (St. Louis, MO). 2-Iodomelatonin and SKF 82958 were obtained from Research Biochemicals, Inc. (Natick, MA). 6-Chloromelatonin was provided by Lily Research Laboratories, Indianapolis, IN. Melatonin, dopamine, cAMP, Dowex 50W-X4 200-400 mesh, neutral alumina, linoleic acid-BSA, glutamine, polyornithine, and pertussis toxin were from Sigma Chemical Co. (St. Louis, MO). Defined fetal bovine serum was from Hyclone (Logan, UT).

\section{Results}

Melatonin receptor-mediated inhibition of dopamine-stimulated cAMP accumulation. Addition of dopamine markedly stimulated cAMP accumulation in cultured retinal cells (see Table 1, Fig. 1). The effect of dopamine was inhibited by the dopamine receptor antagonists SCH 23390 (Table 1) and haloperidol (Fig. 1). Mclatonin ( $100 \mathrm{nM}$ ) had no significant effect on basal cAMP accumulation, but inhibited the stimulation elicited by dopamine by approximately $70 \%$ (Fig. 1). The D1-selective dopamine receptor agonist SKF $82958(100 \mu \mathrm{M})$ also stimulated cAMP accumulation, and its effect was also inhibited by melatonin (Table 2). Melatonin reduced the maximal cAMP response to dopamine without significantly affecting its potency (Fig. 2).

The inhibitory effect of melatonin on dopamine-stimulated cAMP accumulation was concentration-dependent, with an estimated $\mathrm{EC}_{50}$ value (concentration producing a half-maximal effect) of $160 \mathrm{pM}$ and a maximal inhibitory effect of 68\% (Fig. 3 ). The melatonin receptor agonists, 2-iodomelatonin and 6-chloromelatonin, also reduced dopamine-stimulated cAMP ac- 


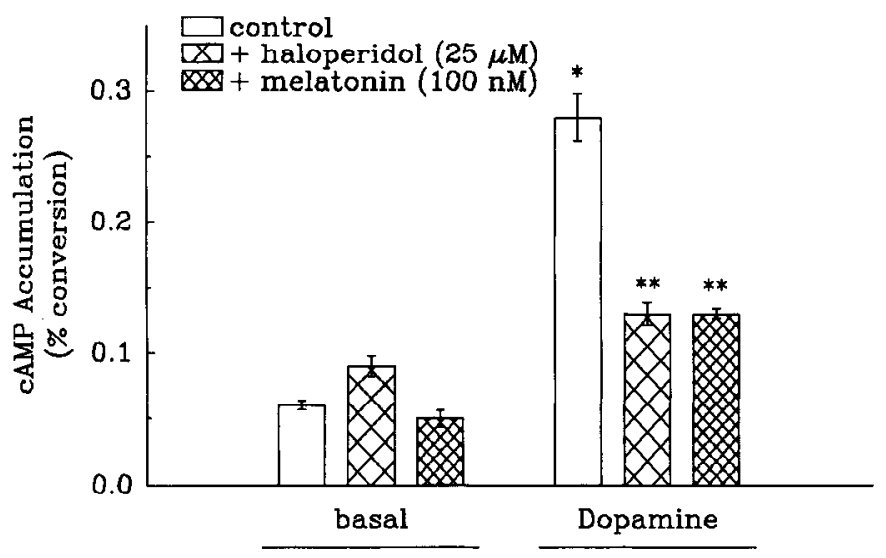

Figure 1. Inhibition of dopamine-stimulated cAMP accumulation by haloperidol and melatonin. cAMP accumulation was determined as described in Material and Methods. Haloperidol $(25 \mu \mathrm{M})$ and melatonin $(100 \mathrm{nM})$ were added $10 \mathrm{~min}$ prior to the addition of dopamine (200 $\mu \mathrm{M}) . N=6 /$ condition. $^{*}, p<0.01$ vs basal; ${ }^{* *}, p<0.01$ vs dopamine.

cumulation, with estimated $\mathrm{EC}_{50}$ values of $35 \mathrm{pM}$ and $260 \mathrm{pM}$, respectively (Fig. 3).

The experiments described above were performed in the absence of a cyclic nucleotide phosphodiesterase inhibitor, and the results could be due to either a stimulation of cAMP breakdown or an inhibition of its formation. The effect of melatonin was therefore reexamined in the presence of 3-isobutyl-1-methylxanthine (IBMX), to address this issue. IBMX $(0.3 \mathrm{mM})$ significantly increased basal cAMP accumulation (Table 3). Melatonin $(300 \mathrm{nM})$ had no effect on the increased accumulation caused by the phosphodiesterase inhibitor. Dopamine markedly stimulated cAMP accumulation in the presence of IBMX, and this stimulation was significantly attenuated by melatonin (Table 3 ). Thus, melatonin appears to inhibit the stimulation of cAMP formation caused by dopamine.

Pretreatment of cultures for $18 \mathrm{hr}$ with pertussis toxin (30 ng/ $\mathrm{ml}$ ) had no effect on dopamine-stimulated cAMP accumulation, but significantly reduced the inhibitory effect of melatonin (Table 4).

Effect of melatonin on inositol phosphate accumulation. Dopamine $(200 \mu \mathrm{M})$ produced a small, but statistically significant stimulation of inositul phosphate accumulation (Table 5), which was inhibited by haloperidol and SCH 23390 (data not shown). Melatonin had no effect on either basal or dopamine-stimulated inositol phosphate accumulation (Table 5). Carbachol, a muscarinic cholinergic receptor agonist, produced a much larger stimulation of inositol phosphate accumulation than did dopamine (Table 5); the effect of carbachol was also unaffected by melatonin.

\section{Discussion}

Previous studies have demonstrated that melatonin modulates dopaminergic neurotransmission in retina by inhibiting dopamine release (Dubocovich, 1983; Nowak, 1988; Boatright et al., 1994). The present results indicate that melatonin may also modulate retinal dopaminergic neurotransmission at a postsynaptic site by inhibiting the cAMP response to D1 dopamine receptor activation. Melatonin, 2-iodomelatonin, and 6-chloromelatonin inhibited dopamine-stimulated cAMP accumulation, a well established response to D1 dopamine receptor activation in retina (Brown and Makman, 1972). The $\mathrm{EC}_{50}$ values for inhibition of

\begin{tabular}{lll}
\hline $\begin{array}{l}\text { Tahle 2. Melatonin inhibits SKF82958-stimulated cAMP } \\
\text { accumulation }\end{array}$ & $N$ & $\begin{array}{l}\text { cAMP accumulation } \\
\text { (\% conversion) }\end{array}$ \\
Addition & 5 & $0.38 \pm 0.04$ \\
Vehicle & 6 & $0.31 \pm 0.03$ \\
Melatonin $(100 \mathrm{nM})$ & 6 & $0.92 \pm 0.19^{a}$ \\
SKF82958 $(100 \mu \mathrm{M})$ & 5 & $0.59 \pm 0.04^{b}$ \\
Melatonin + SKF82958 &
\end{tabular}

$a p<0.01$ versus vehicle.

${ }^{b} p<0.05$ versus SKF82958.

dopamine-stimulated cAMP accumulation by melatonin and related agonists are similar to those for inhibition of chick retinal dopamine release (Dubocovich and Takahashi, 1987) and to the $K_{i}$ values for inhibition of ${ }^{2-125}$ I-iodomelatonin binding to chick brain slices (Siuciak et al., 1991) and retinal neurons (Iuvone and Gan, unpublished observation). The $\mathrm{EC}_{50}$ for inhibition of dopamine-stimulated cAMP accumulation by 2-iodomelatonin (35 pM) is virtually identical to the equilibrium dissociation constant $\left(K_{D}\right)$ for 2-125I-iodomelatonin binding to chick retinal neurons in culture ( $42 \mathrm{pM}$; Iuvone and Gan, 1994a). Thus, melatonin and its analogs inhibit dopamine-stimulated cAMP accumulation by activating melatonin receptors similar to those described pre-

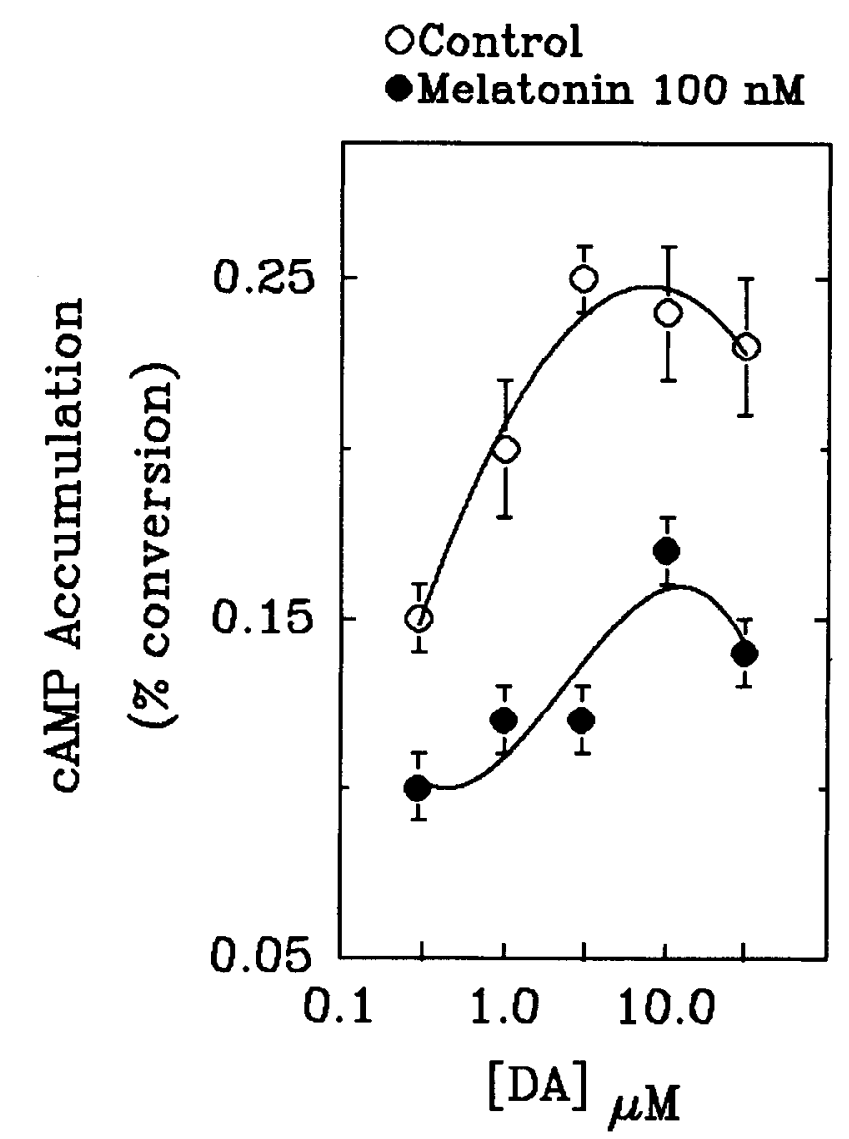

Figure 2. Concentration-response analysis of dopamine-stimulated cAMP accumulation in the presence and absence of melatonin (100 nM). Melatonin reduced the maximal response to dopamine but had no significant effect on its potency; $E_{50}$ values were 0.74 and 1.1 in the absence and presence of melatonin, respectively $(p>0.05)$. Melatonin significantly $(p<0.01)$ reduced cAMP accumulation at all dopamine concentrations. $N=7-8 /$ data point. 


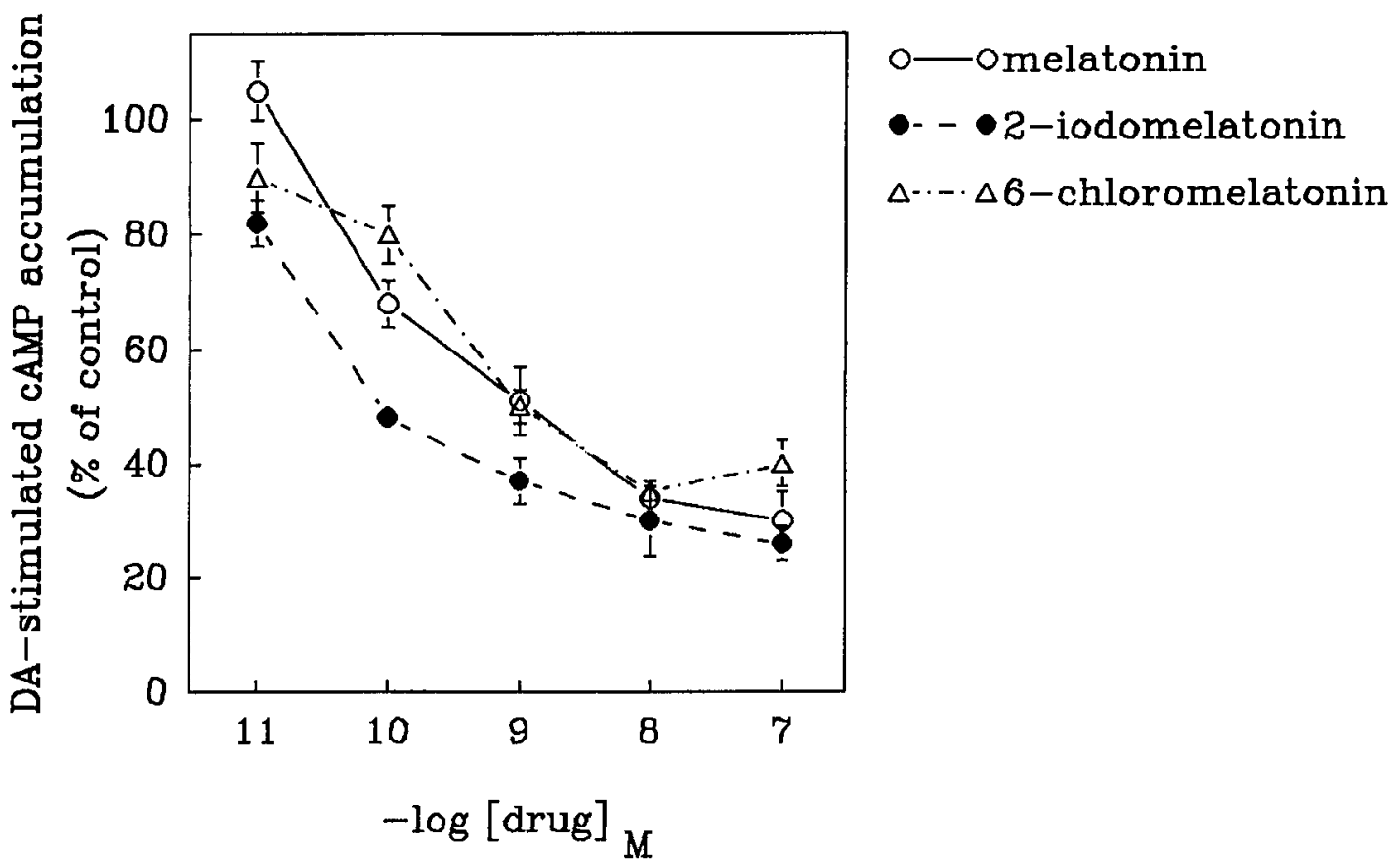

Figure 3. Concentration-response analysis for inhibition of dopamine-stimulated cAMP accumulation by melatonin and halogenated analogs. The rank order of potency for inhibition of dopamine-stimulated cAMP accumulation was 2-iodomelatonin $>$ melatonin $\geq 6$-chloromelatonin (see text for $\mathrm{EC}_{50}$ values). Sample sizes: melatonin, 9-11/data point; 2-iodomelatonin, 4-6/data point; 6-chloromelatonin, 4-5/data point.

viously using other functional or binding assays. Furthermore, the inhibitory effect of melatonin on dopamine-stimulated cAMP accumulation was blocked by pretreatment with pertussis toxin, which also attenuates the inhibition by melatonin of forskolin-stimulated cAMP accumulation in retinal cells (Iuvone and Gan, 1994), brain (Niles et al., 1991), and pars tuberalis (Morgan et al., 1990). Thus, we suggest that melatonin stimulates receptors located on neurons that also contain D1 dopamine receptors, and that the melatonin receptors activate a $\mathrm{G}_{\mathrm{i}}$-like guanyl nucleotide binding protein that inhibits the effect of $\mathrm{G}_{s}$ activation by DI dopamine receptor stimulation.

D1 dopamine receptors in brain have been reported to be coupled to phospholipase C (Undie and Friedman, 1992), activation of which stimulates inositol phosphate formation and activation of protein kinase C (Nishizuka, 1992). We recently demonstrated that dopamine stimulates inositol phosphate accumulation in cultured neural retinal cells by activating a receptor with the phar-

Table 3. Melatonin inhibits dopamine-stimulated cAMP accumulation in the presence of IBMX

\begin{tabular}{ll} 
Addition & $\begin{array}{l}\text { cAMP accumulation } \\
\text { (\% conversion) }\end{array}$ \\
\hline Vehicle & $0.07 \pm 0.004$ \\
IBMX $(0.3 \mathrm{mM})$ & $0.29 \pm 0.02^{a}$ \\
IRMX & \\
$\quad$ +Melatonin $(300 \mathrm{nM})$ & $0.29 \pm 0.01^{a}$ \\
$\quad$ +Dopamine $(10 \mu \mathrm{M})$ & $1.88 \pm 0.04^{b}$ \\
$\quad$ +Melatonin and dopamine & $1.34 \pm 0.06^{c}$
\end{tabular}

IBMX was added, where indicated, during the preincubation prior to stimulation with dopamine. $N=5-6 /$ condition.

${ }^{a} p<0.01$ versus vehicle control.

${ }^{b} p<0.01$ versus IBMX control.

${ }^{c} p<0.01$ versus IBMX + dopamine. macological characteristics of a D1 dopamine receptor (Iuvone and Gan, 1994b). Remarkably, melatonin inhibits the cAMP response to dopamine but not dopamine-stimulated inositol phosphate accumulation. Thus, melatonin receptors may be colocalized with D1 receptors that are coupled to adenylate cyclase, but not with D1-like receptors that are coupled to phospholipase C. Alternatively, all three receptor-effector complexes may be colocalized, with melatonin receptors capable of inhibiting $\mathrm{G}_{\mathrm{s}}$-mediated adenylate cyclase activation, but not the stimulation of phospholipase $\mathrm{C}$ by $\mathrm{G}_{\mathrm{q}}$ or related $\mathrm{G}$ proteins. In retina, D1 dopamine receptors coupled to both adenylate cyclase and phospholipase $\mathrm{C}$ may be colocalized on horizontal cells. cAMP mediates the effects of dopamine on horizontal cell gap junction permeability and on glutamate-gated cation conductance (Dowling, 1989), while the effects of dopamine on horizontal cell neurite extension and spinule formation may involve activation of phospholipase C (Dos Santos Rodrigues and Dowling, 1990; Weiler et al., 1991). These observations suggest a novel mechanism for modulation of dopaminergic neurotransmission, whereby melatonin interferes with some, but not all of the consequences of dopamine receptor activation.

Melatonin also failed to alter the stimulation of inositol phosphate accumulation in retinal cell cultures in response to activation of muscarinic cholinergic receptors with carbachol. This result is consistent with a preliminary report that melatonin does not inhibit carbachol-stimulated inositol phosphate accumulation in chick brain slices (Fang et al., 1990). Melatonin also failed to alter $\mathrm{AlF}_{4}$-induced inositol phosphate accumulation in ovine pars tuberalis (Morgan et al., 1991), suggesting that melatonin receptors are not negatively coupled to $G$ protein-stimulated phospholipase $\mathrm{C}$.

Dopamine-melatonin interactions are not unique to retina, but occur in other parts of the CNS as well. Melatonin inhibits hypothalamic dopamine release (Zisapel and Laudon, 1983) and 
Table 4. Pretreatment with pertussis toxin hlocks the inhibition of dopamine-stimulated cAMP accumulation by melatonin

\begin{tabular}{lll} 
& \multicolumn{2}{l}{ cAMP accumulation } \\
\cline { 2 - 3 } Addition & Without toxin & + Pertussis toxin \\
\hline Vehicle & $0.46 \pm 0.02$ & $0.51 \pm 0.03$ \\
Dopamine $(200 \mu \mathrm{M})$ & $0.84 \pm 0.02^{a}$ & $0.79 \pm 0.02^{c}$ \\
Dopamine + Inelatonin $(300 \mathrm{nM})$ & $0.57 \pm 0.03^{b}$ & $0.74 \pm 0.03^{d}$
\end{tabular}

Cultures were pretreated with pertussis toxin $(30 \mathrm{ng} / \mathrm{ml})$ for $18 \mathrm{hr}$, as described in Materials and Methods, prior to labeling cells with ${ }^{3} \mathrm{H}$-adenine. $N=5-6 /$ condition.

${ }^{a} p<0.01$ versus vehicle control.

${ }^{b} p<0.01$ versus dopamine control.

" $p<0.01$ versus vehicle + pertussis toxin.

${ }^{d} p<0.05$ versus dopamine.

reduces the dopamine content of the neurointermediate lobe of the pituitary gland (Alexiuk and Vriend, 1993). Dopamine and melatonin may interact to regulate pituitary gonadotropin release (Acuña-Castroviejo et al., 1993). Furthermore, it has been suggested that interactions of dopamine and melatonin in the nucleus accumbens may play a role in the behavioral response to antidepressant drugs (Durlach-Misteli and Van Ree, 1992).

Based on the present results, we propose the following working hypothesis for modulation of dopaminergic transmission by melatonin (Fig. 4). Melatonin may inhibit dopamine release at a presynaptic site (Dubocovich, 1983; Boatright et al., 1994). The effect of melatonin on dopamine release is dependent on GABAergic neurotransmission, as it is completcly blocked by GABA receptor antagonists (Boatright et al., 1994). It is unclear if melatonin acts to increase the synaptic concentration of GABA or to enhance the response to GABA at a postsynaptic site. In addition, melatonin inhibits the stimulation of adenylate cyclase by D1 dopamine receptor activation at a postsynaptic site. We propose that melatonin receptors and cyclase-coupled D1 dopamine receptors are colocalized in the same neurons, but can not exclude the possibility that melatonin acts on other cells, which release a neurotransmitter that modulates dopamine-stimulated adenylate cyclase activity. In contrast, melatonin has no effect on dopamine-stimulated activation of phospholipase C. It is unclear at present if the cyclase-coupled dopamine receptors and the D1-like receptors linked to phospholipase $\mathrm{C}$ are co-localized or exist on different neurons. It is also not known if melatonin modulates responses to D2 dopamine receptor activation. Mclatonin maximally inhibits endogenous dopamine re

\section{Table 5. Melatonin does not inhibit inositol phosphate} accumulation in retinal neurons

Inositol phosphates (\% hydrolysis)

\begin{tabular}{|c|c|c|}
\hline \multirow[b]{2}{*}{ Condition } & \\
\hline & Without mclatonin & +Melatonin \\
\hline \multicolumn{3}{|l|}{ Experiment I } \\
\hline Basal & $6.4 \pm 0.3$ & $5.7 \perp 0.8$ \\
\hline Dopamine $200 \mu \mathrm{M}$ & $10.0 \pm 0.8^{a}$ & $10.1 \pm 0.9^{a}$ \\
\hline \multicolumn{3}{|l|}{ Experiment II } \\
\hline Basal & $7.4 \pm 0.2$ & $6.8 \pm 0.2$ \\
\hline Carbachol $500 \mu \mathrm{M}$ & $20.4 \pm 0.8^{a}$ & $21.0 \pm 0.8^{\alpha}$ \\
\hline
\end{tabular}

Melatonin concentration was $100 \mathrm{nM}$ in experiment I and $300 \mathrm{nM}$ in experiment II. Inositol phosphate accumulation was determined as described in Materials and Methods. $N=5-6 /$ condition.

${ }^{a} p<0.05$ versus basal. lease by $50-70 \%$. Thus, in the presence of melatonin, dopaminergic transmission may be modulated by a combination of reduced dopamine release and a selective reduction of some postsynaptic responses to dopamine receptor aclivation.

We emphasize the hypothetical nature of this model, which is intended to present a framework for the design of additional experiments. The functional interaction of melatonin receptors and D1 dopamine receptors has only been investigated in cell cultures of embryonic retinal neurons. The cell types generating the observed responses are not yet identified. Additionally, it will be important to determine if a similar functional interaction occurs in intact, adult retina.

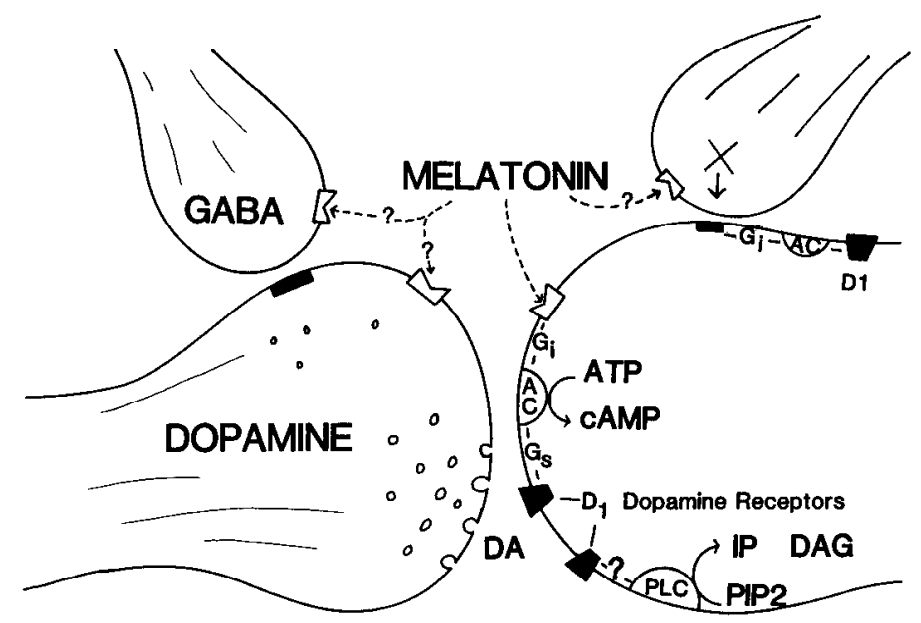

Figure 4. Hypothetical model for the modulation of dopaminergic neurotransmission by melatonin. Melatonin receptor activation inhibits dopamine release by a mechanism that involves GABAergic neurotransmission (Boatright et al., 1994). Postsynaptically, D1 dopamine receptors are coupled to adenylate cyclase $(A C)$ by the stimulatory guanyl nucleotide-binding protein $\mathrm{G}_{3}$. Melatonin receptor activation inhibits dopamine-stimulated AC activity via a pertussis toxin-sensitive $G$ protein, such as $G_{i}$. We propose that this functional interaction occurs via melatonin receptors and dopamine receptors that are colocalized on the same postsynaptic membrane. However, the possibility that melatonin acts on other neurons, which release a neurotransmitter $(X)$ that modulates dopamine-stimulated adenylate cyclase, cannot be excluded. D1like dopamine receptors also appear to activate phospholipase $\mathrm{C}(P L C)$ (Iuvone and Gan, 1994b), which converts phosphatidylinositol 4,5 bisphosphate (PIP2) into two second messengers, inositol trisphosphate (IP3) and diacylglycerol (DAG). Melatonin has no effect on this response. Thus, melatonin may modulate dopaminergic transmission by a combination of reducing dopamine release and inhibiting some of the postsynaptic responses to dopamine receptor activation. 


\section{References}

Acuña-Castroviejo D, Fernández B, Castillo JL, Del Aguila CM (1993) Similarity between the effects of suprachiasmatic nuclei lesions and of pinealectomy on gonadotropin release in ovariectomized, sulpiride-treated and melatonin-replaced rats. Experientia 49:797-801.

Adler R, Lindsey JD, Elsner CL (1984) Expression of cone-like properties by chick embryo retina cells in glial-free monolayer cultures. J Cell Biol 99:1173-1178.

Alexiuk NAM, Vriend JP (1993) Melatonin reduces dopamine content in the neurointermediate lobe of male Syrian hamsters. Brain Res Bull 32:433-436.

Avendano G, Butler BJ, Iuvone PM (1990) $\mathrm{K}^{+}$-Evoked depolarization increases serotonin $N$-acetyltransferase activity in photoreceptor-enriched retinal cell cultures. Involvement of calcium influx through L-type calcium channels. Ncurochem Int 17:117-126.

Berridge MJ, Downes CP, Hanley MR (1982) Lithium amplifies agonist-dependent phosphatidylinositol responses in brain and salivary glands. Biochem J 206:587-595.

Besharse JC, Dunis DA (1983) Methoxyindoles and photoreceptor metabolism: activation of rod shedding. Science 219:1341-1343.

Besharse JC, Iuvone PM (1983) Circadian clock in Xenopus eye controlling retinal serotonin $N$-acetyltransferase. Nature 305:133-135.

Besharse JC, Dunis DA, Iuvone PM (1984) Regulation and possible role of serotonin $N$-acetyltransferase in the retina. Fed Proc 43:27042708.

Besharse JC, Iuvone PM, Pierce ME (1988) Regulation of rhythmic photoreceptor metabolism: a role for post-receptoral neurons. In: Progress in retinal research (Osborne N, Chader GJ, eds), pp 21-61. Oxford: Pcrgamon.

Boatright JH, Hoel MJ, Iuvone PM (1989) Stimulation of endogenous dopamine release and metabolism in amphibian retina by light and $\mathrm{K}^{+}$-evoked depolarization. Brain Res 482:164-168.

Boatright JH, Rubim NM, I vone PM (1994) Regulation of endogenous dopamine release in mphibian retina by melatonin: the role of GABA. Vis Neurosci, in ] ess.

Brown JH, Makman MH (16 12) Stimulation by dopamine of adenylate cyclase in retinal homoge ates and of adenosine- $3^{\prime}: 5^{\prime \prime}$-cyclic monophosphate formation in tact retina. Proc Natl Acad Sci USA 69: 539-543.

Cahill GM, Besharse IC. (1991) Resetting the circadian clock in cultured Xenopus eyecups: regulation of retinal melatonin rhythms by light and $D_{2}$ dopamine receptors. J Neurosci 11:2959-2971.

Cahill GM, Besharse JC (1992) Light-sensitive melatonin synthesis by Xenopus photoreceptors after destruction of the inner retina. Vis Neurosci 8:487-490.

Cheze G, Ali MA (1976) Role de l'epiphyse dans la migration du pigment epithelial retinien chez quelques Teleosteens. Can J Zool 54: 475-481.

Dearry A, Burnside B (1986) Dopaminergic regulation of cone retinomotor movement in isolated teleost retinas. I. Induction of cone contraction is mediated by D2 receptors. J Neurochem 46:1006-1021.

DeLean A, Munson PJ, Rodbard D (1978) Simultaneous analysis of families of sigmoidal curves: application to bioassay, radioligand assay, and physiological dose-response curves. Am J Physiol 235:E97E102.

DeMello MCF, Ventura ALM, Paes de Carvalho R, Klein WL, deMello FG (1982) Regulation of dopamine- and adenosine-dependent adenylate cyclase systems of chicken embryo retina cells in culture. Proc Natl Acad Sci USA 79:5708-5712.

Dos Santos Rodrigues P, Dowling JE (1990) Dopamine induces neurite retraction in retinal horizontal cells via diacylglycerol and protein kinase C. Proc Natl Acad Sci USA 87:9693-9697.

Dowling JE (1989) Neuromodulation in the retina: the role of dopamine. Semin Neurosci 1:35-43.

Dowling JE, Watling KJ (1981) Dopaminergic mechanisms in the teleost retina. II. Factors affecting the accumulation of cAMP in pieces of intact carp retina. J Neurochem 36:569-579.

Dubocovich ML (1983) Melatonin is a potent modulator of dopamine release in the retina. Nature 306:782-784.

Dubocovich ML, Takahashi JS (1987) Use of 2-[125I]-iodomelatonin to characterize melatonin binding sites in chicken retina. Proc Natl Acad Sci USA 84:3916-3920.

Durlach-Misteli C, Van Ree JM (1992) Dopamine and melatonin in the nucleus accumbens may be implicated in the mode of action of antidepressant drugs. Eur J Pharmacol 217:15-21.
Ehinger B (1977) Synaptic connections of the dopaminergic retinal neurons. Adv Biochem Psychopharmacol 16:299-306.

Fang JM, McMasters KN, Dubocovich ML (1990) Carbachol stimulates phosphoinositide (PI) turnover in chick brain slices: effect of melatonin. Soc Neurosci Abstr 16:374.

Gallemore RP, Steinberg RH (1990) Effects of dopamine on the chick retinal pigment epithelium: membrane potentials and light-evoked responses. Invest Ophthalmol Vis Sci 31:67-80.

Godley BF, Wurtman RJ (1988) Release of endogenous dopamine from the superfused rabbit retina in vitro: effect of light stimulation. Brain Res 452:393-395.

Hamm HE, Menaker M (1980) Retinal rhythms in chicks-circadian variation in melatonin and serotonin $N$-acetyltransferase. Proc Natl Acad Sci USA 77:4998-5002.

Hensler JG, Dubocovich ML (1986) D1-dopamine receptor activation mediates ${ }^{3} \mathrm{H}$-acetylcholine release from rabbit retina. Brain Res 398 : 407-412.

Iuvone PM (1986) Neurotransmitters and neuromodulators in the retina: regulation, interactions and cellular effects. In: The retina, a model for cell biology studies, Pt II (Adler R, Farber D, eds), pp 1-72. Orlando: Academic

Iuvone PM, Besharse JC (1986) Dopamine receptor-mediated inhibition of serotonin $N$-acetyltransferase activity in retina. Brain Res 369 : 168-176.

Iuvone PM, Gan J (1992) Melatonin receptor-mediated inhibition of dopamine stimulated and forskolin-stimulated cyclic AMP accumulation in chick retinal cell cultures. Invest Ophthalmol Vis Sci 33: 1405.

Iuvone PM, Gan J (1994a) Melatonin receptor-mediated inhibition of cyclic AMP accumulation in chick retinal cell cultures. J Neurochem 63:118-124

Iuvone PM, Gan J (1994b) Stimulation of inositol phosphate accumulation in retinal neurons via activation of Dl-like dopamine receptors. Invest Ophthalmol Vis Sci 35:2154.

Iuvone PM, Galli CL, Garrison-Gund CK, Neff NH (1978) Light stim ulates tyrosine hydroxylase activity and dopamine synthesis in retinal amacrine neurons. Science 202:901-902.

Iuvone PM, Boatright JH, Bloom MM (1987) Dopanine mediates the light-evoked suppression of serotonin $\mathrm{N}$-acetyltransferase activity in retina. Brain Res 418:314-324.

Iuvone PM, Avendano G, Butler BJ, Adler R (1990) Cyclic AMPdependent induction of serotonin $N$-acetyltransferase activity in photoreceptor-enriched chick retinal cell cultures: characterization and inhibition by dopamine. J Neurochem $55: 673-682$.

Kramer SG (1971) Dopamine: a retinal neurotransmitter. I. Retinal uptake, storage, and light stimulated release of $\mathrm{H3}$-dopamine in vivo. Invest Ophthalmol 10:438-452.

Laitinen JT, Saavedra JM (1990) The chick retinal melatonin receptor revisited: localization and modulation of agonist binding with guanine nucleotides. Brain Res 528:349-352.

Mangel SC, Dowling JE (1987) The interplexiform-horizontal cell system of the fish retina: effects of dopamine, light stimulation and time in the dark. Proc R Soc Lond [Biol] 231:91-121.

Minneman KP, Hegstrand LR, Molinoff PB (1979) The pharmacological specificity of beta-1 and beta-2 adrenergic receptors in rat heart and lung in vitro. Mol Pharmacol 16:21-33.

Mitchell CK. Redburn DA (1991) Melatonin inhibits ACh release from rabbit retina. Vis Neurosci 7:479-486.

Morgan PJ, Davidson G, Lawson W, Barrett P (1990) Both pertussis toxin-sensitive and insensitive G-proteins link melatonin receptor to inhibition of adenylate cyclase in the ovine pars tuberalis. J Neuroendocrinol 2:773-776.

Morgan PJ, Hastings MH, Thompson M, Barrett P, Lawson W, Davidson $G$ (1991) Intracellular signalling in the ovine pars tuberalis: an investigation using aluminum fluoride and melatonin. J Mol Endocrinol 7:137-144.

Nao IN, Nilsson SEG, Gallemore RP, Steinberg RH (1989) Effects of melatonin on the chick retinal pigment epithelium: membrane potentials and light-evoked responses. Exp Eye Res 49:573-589.

Niles LP, Ye M, Pickering DS, Ying S-W (1991) Pertussis toxin blocks melatonin-induced inhibition of forskolin-stimulated adenylate cyclase activity in the chick brain. Biochem Biophys Res Commun 178: 786-792.

Nishizuka Y (1992) Intraccllular signaling by hydrolysis of phospholipids and activation of protein kinase $C$. Science 258:607-614. 
Nowak JZ (1988) Melatonin inhibits ${ }^{3} \mathrm{H}$-dopamine release from rabbit retina by light, potassium, and electrical stimulation. Med Sci Res 16:1073.

Nowak JZ, Kazula A, Golembiowska K (1992) Melatonin increases serotonin $N$-acetyltransferase activity and decreases dopamine synthesis in light-exposed chick retina: in vivo evidence supporting melatonin-dopamine interaction in retina. J Neurochem 59:1499-1505.

Pang SF, Yew DT (1979) Pigment aggregation by melatonin in the retinal pigment epithelium and choroid of guinea pigs, Cavia pocellus. Experientia 35:231-233.

Parkinson D, Rando RR (1983) Effects of light on dopamine metabolism in the chick retina. J Neurochem 40:39-46.

Pierce ME, Besharse JC (1985) Circadian regulation of retinomotor movements. I. Interaction of melatonin and dopamine in the control of cone length. J Gen Physiol 86:671-689.

Pierce ME, Besharse JC (1986) Melatonin and dopamine interactions in the regulation of rhythmic photoreceptor metabolism. In: Pineal and retinal relationships (O'Brien PJ, Klein DC, eds), pp 219-237. Orlando: Academic.

Redburn DA, Mitchell CK (1989) Darkness stimulates rapid synthesis and release of melatonin in rat retina. Vis Neurosci 3:391-403.

Rudolf G, Vivien-Roels B, Pévet P, Kempf E, Wioland N (1992) Dopamine and melatonin interactions in the intact chicken eye. Electrooculographic and biochemical study. Brain Res 584:64-70.

Shimizu H, Daly JW, Creveling CR (1969) A radioisotopic method for measuring the formation of adenosine $3^{\prime}, 5^{\prime}$-cyclic monophosphate in incubated slices of brain. J Neurochem 16:1609-1619.

Siuciak JA, Krause DN, Dubocovich ML (1991) Quantitative pharmacological analysis of 2-125I-iodomelatonin binding sites in discrete areas of the chicken brain. J Neurosci 11:2855-2864.

Thomas KB, Tigges M, Iuvone PM (1993) Melatonin synthesis and circadian tryptophan hydroxylase activity in chicken retina following destruction of serotonin immunoreactive amacrine and bipolar cells by kainic acid. Brain Res 601:303-307.
Undie AS, Friedman E (1992) Selective dopaminergic mechanism of dopamine and SKF38393 stimulation of inositol phosphate formation in rat brain. Eur J Pharmacol Mol Pharmacol 226:297-302.

Watling KJ, Dowling JE, Iversen LL (1979) Dopamine receptors in the retina may all be linked to adenylate cyclase. Nature 281:578-580.

Weiler R, Kohler K, Janssen U (1991) Protein kinase C mediates transient spinule-type neurite outgrowth in the retina during light adaptation. Proc Natl Acad Sci USA 88:3603-3607.

Wiechmann AF, Craft CM (1993) Localization of mRNA encoding the indolamine synthesizing enzyme, hydroxyindole- $O$-methyltransferase, in chicken pineal gland and retina by in situ hybridization. Neurosci Lett 150:207-211.

Wiechmann AF, Wirsig-Wiechmann CR (1991) Localization and quantification of high-affinity melatonin binding sites in Rana pipiens retina. J Pineal Res 10:174-179.

Wiechmann AF, Yang X-L, Wu SM, Hollyfield JG (1988) Melatonin enhances horizontal cell sensitivity in salamander retina. Brain Res 453:377-380.

Wilson KM, Gilchrist S, Minneman KP (1990) Comparison of $\alpha_{1}$ adrenergic receptor-stimulated inositol phosphate formation in primary neuronal and glial cultures. J Neurochem 55:691-697.

Zawilska J, Iuvone PM (1989) Catecholamine receptors regulating serotonin $N$-acetyltransferase activity and melatonin content of chicken retina and pineal gland: $\mathrm{D}_{2}$-dopamine receptors in retina and alpha-2 adrenergic receptors in pineal gland. J Pharmacol Exp Ther 250:8692.

Lawilska JB, Iuvone PM (1992) Melatonin synthesis in chicken retina: effect of kainic acid-induced lesions on the diurnal rhythm and $\mathrm{D}_{2-}$ dopamine receptor-mediated regulation of serotonin $\mathrm{N}$-acetyltransferase activity. Neurosci Lett 135:71-74.

Zisapel N, Laudon M (1983) Inhibition by melatonin of dopamine release from rat hypothalamus: regulation by calcium entry. Brain Res 272:378-381. 